\title{
An analysis of the selected sociodemographic characteristics in removable denture wearers
}

\begin{abstract}
Introduction. Dental prosthetic replacements allow restoring the masticatory function, thus contributing to proper nutrition and correct speech, and also improving facial aesthetics.

Aim. The aim of the study was to assess the selected sociodemographic characteristics of people using removable dentures (patient-paid and funded by the National Health Fund).

Material and methods. A questionnaire survey involved 321 individuals, resident in the Lubelskie Voivodship, who used removable dental prostheses. Their selected sociodemographic characteristics were analysed: age, sex, education, place of residence and material status, as well as the form of payment for prosthetic replacements. The obtained results were analysed statistically.

Results. Almost $70 \%$ of the studied population wearing removable prostheses had their dentures funded by the National Health Fund. In each age group, women used National Health Fund funded prostheses twice more frequently than men. Prostheses funded by the National Health Fund were used significantly more frequently by patients aged 51-70 years, living in cities and with a higher education level, in comparison to the respondents from other age groups, with different place of residence and education level.

Conclusions. There is correlation between sex, age, place of residence and education level of patients and the frequency of their wearing removable dentures, both patient-paid and funded by the National Health Fund.
\end{abstract}

Keywords: removable dentures, sociodemographic characteristics, forms of payment.

DOI: $10.2478 / \mathrm{pjph}-2014-0015$

\section{INTRODUCTION}

Oral health, including the number of teeth in the oral cavity in elderly people, is an important problem in Poland and in the world, especially that the average life span is increasing. The loss of teeth can lead to numerous negative consequences. The prosthetic treatment of partial or complete edentulism allows, on the one hand, the restoration of the masticatory organ function, thus improving the patient's physical condition, and on the other, improves his or her psychological wellbeing [1]. Epidemiological research of the Polish population showed that in the group of 65-74 years old people, $41.6 \%$ were edentulous [2], and the need of prosthetic treatment, e.g. in the Lódzkie Voivodship, reached the level of $42 \%$ in the age group 35-44 years [3]. The number of individuals in need of complete dentures in the USA was assessed in 1991 as 36.6 million, and the expected number of such patients in 2020 is 37.9 million [4].

\begin{abstract}
AIM
The aim of the study was to assess the selected sociodemographic characteristics of people wearing removable dentures, both patient-paid and funded by the National Health Fund.

\section{MATERIAL AND METHODS}

A questionnaire survey involved 321 individuals, resident in the Lubelskie Voivodship, who used removable dental prostheses. Their selected sociodemographic characteristics were analysed: age, sex, education, place of residence and material status, as well as the form of payment for prosthetic replacements. The obtained results were analysed statistically. The values of the analysed parameters, measured in the nominal scale, were characterized with size and percentage, while the correlations between the analysed characteristics were assessed with $\mathrm{Chi}^{2}$ independence test and $\log$-linear analysis. The assumed error of estimation was $5 \%$, and the related significance level $\mathrm{p}<0.05$ indicated statistically significant differences. The analysed database and statistical analysis were performed with Statistica 10.0 (StaSoft, Poland).
\end{abstract}

\footnotetext{
${ }^{1}$ Department of Dental Prosthetics, Medical University of Lublin, Poland

${ }^{2}$ Department of Mathematics and Medical Biostatistics, Medical University of Lublin, Poland

${ }^{3}$ Chair and Department of Paedodontics, Medical University of Lublin, Poland
} 


\section{RESULTS}

The respondents were 321 individuals aged from 23 to 83 years. The average age of the studied population was $58.5 \pm 9.7$ years. The study involved 219 women (68.2\%) and 102 men $(31.8 \%)$. The average age of women was $59.1 \pm 9.8$ years, while that of men $-57.4 \pm 9.2$ years. The observed differences were not statistically significant $(t=1.47 ; \mathrm{df}=319 ; \mathrm{p}=0.14)$.

The structure of age in the studied population was following: 58 respondents $(18.1 \%)$ were younger than 50 years, 225 respondents $(70.1 \%)$ were $51-70$ years, and 38 respondents $(11.8 \%)$ were older than 70 years $(11.8 \%)$. In the studied population 69 respondents $(21.5 \%)$ had primary education, $111(34.6 \%)$ - vocational education, $119(3.1 \%)$ - secondary, $11(3.4 \%)$ - postsecondary, while $2(0.6 \%)$ and $8(2.5 \%)$ had, respectively, bachelor's and master's degrees. One respondent did not provide information on his education. The city was the place of residence for the majority of respondents (214 people): 117 lived in a city of 200,000 population, 31 - in a 50,000-200,000 city, 66 - in a city with less than 50,000 population, while 107 respondents lived in a village. The respondents' income was determined on the basis of the amount per family members in 5 suggested ranges. 65 respondents $(20.2 \%)$ indicated the range where the amount per family members was lower than 500 PLN, $74(23.1 \%)$ indicated the 500-800 PLN range, 77 respondents $(24.0 \%)$ - more than 800 PLN, but no more than 1000 PLN. There were $74(23.1 \%)$ respondents with an income of less than 1000 PLN, but no more than 1500 , and $28(8.7 \%)$ respondents with an income of more than 1500 . Three respondents did not provide information on their income $(0.9 \%)$.

224 respondents $(69.8 \%)$ had their dentures made free of charge (funded by the National Health Fund), while 97 respondents paid for their dentures privately.

To analyse the influence of education on the form of payment for removable dentures, the respondents were divided into two categories: group I included patients with primary and vocational education, group II - those with at least secondary education. No statistically significant differences were found within each group $\left(\mathrm{Chi}^{2}=2.198 ; \mathrm{df}=2\right.$; $\mathrm{p}=0.334$ ). Both patients with lower education level and those with at least secondary education used dentures funded by the National Health Fund more frequently.

To identify the variables that influence the different forms of payment for removable dentures, the effect of the following factors: sex $(1-\mathrm{w} ; 2-\mathrm{m})$, age $(1-$ younger than $50 ; 2-50-70$; 3 - older than 70 ), place of residence ( 1 - village; 2 - city), material status $(1-$ less than 500 PLN per family member; 2 - no more than 1000 PLN; 3 - more than 1000 PLN) on the payment form ( 1 - funded prosthesis; 2 - patient-paid prosthesis) was analysed using log-linear analysis.

The analysis showed that city inhabitants significantly more frequently used prostheses funded by the National Health Fund $\left(\mathrm{Chi}^{2}=6.908 ; \mathrm{p}=0.008 ; \mathrm{OR}=0.51\right.$ in $0.31-0.84$ bracket $)$. The odds ratio (OR) indicates that city residents have twice greater possibility to use a partial denture funded by the National Health Fund in comparison to the respondents who lived in villages (Table 1). It was also found that the percentage of the respondents wearing prostheses funded by the National Health Fund increased together with an increase of income $\left(\mathrm{Chi}^{2}=4.67\right.$; $\mathrm{p}=0.031 ; \mathrm{OR}=0.81$ in $0.67-0.98$ bracket) (Table 2 ).
TABLE 1. Payment for removable dentures according to place of residence.

\begin{tabular}{lccc}
\hline \hline \multirow{2}{*}{ Form of payment } & \multicolumn{3}{c}{ Place of residence } \\
\cline { 2 - 4 } & Village & City & Total \\
\hline Patient-paid prosthesis & 43 & 55 & 98 \\
\hline $\begin{array}{l}\text { Prosthesis funded } \\
\text { by the National Health Fund }\end{array}$ & 64 & 159 & 223 \\
\hline Total & 107 & 214 & 321 \\
\hline
\end{tabular}

TABLE 2. Payment for removable dentures according to income level.

\begin{tabular}{lcccc}
\hline \hline \multirow{2}{*}{ Form of payment } & \multicolumn{4}{c}{ Income level } \\
\cline { 2 - 5 } & $<500$ PLN & $500-1000$ PLN $>1000$ PLN & Total \\
\hline $\begin{array}{l}\text { Patient-paid } \\
\text { prosthesis }\end{array}$ & 22 & 53 & 22 & 97 \\
\hline $\begin{array}{l}\text { Prosthesis funded } \\
\text { by the National }\end{array}$ & 40 & 98 & 83 & 221 \\
$\begin{array}{l}\text { Health Fund } \\
\text { Total }\end{array}$ & 62 & 151 & 105 & 321 \\
\hline
\end{tabular}

Both among men and women, the highest percentages of respondent wearing funded prostheses were found in the age group 51-70 years. A comparison of the percentages of men with those of women showed that in each age group women significantly more often $\left(\mathrm{Chi}^{2}=6.21 ; \mathrm{df}=2 ; \mathrm{p}=0.04\right)$ used dentures funded by the National Health Fund (younger than 50 $-7.5 \%$ vs $5.3 \%$; $51-70$ years $-31.2 \%$ vs $15.6 \%$; and older than $70-8.4 \%$ vs $1.6 \%$ (Figure 1 ).

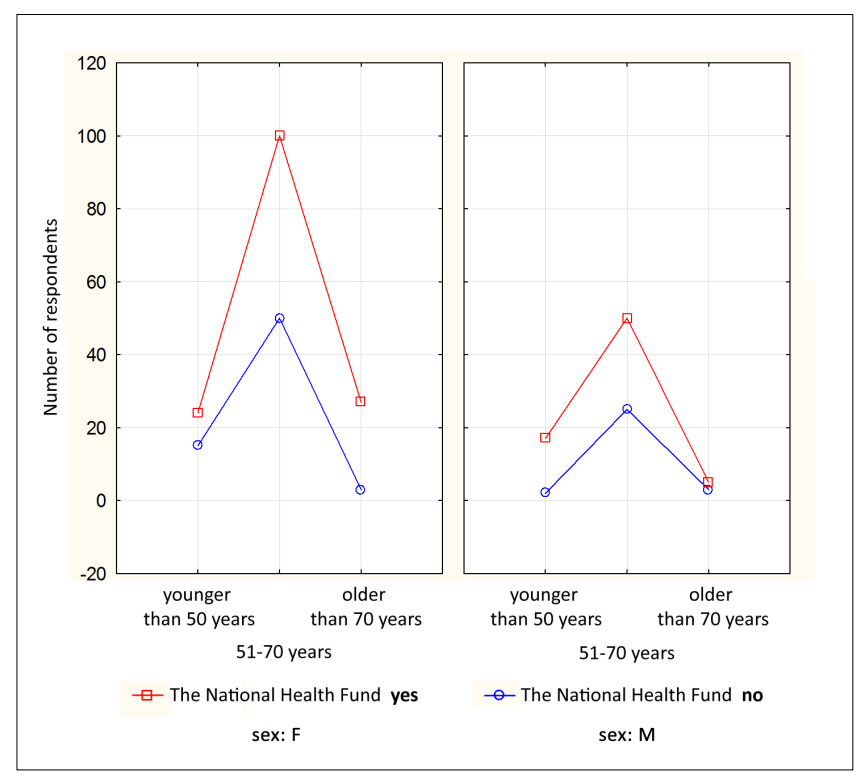

FIGURE 1. Interaction between sex and age of removable denture wearers and payment form.

\section{DISCUSSION}

The results of our study indicate the correlation between sex, age, place of residence, and education, on the one hand, and the frequency of their wearing removable dentures, both patient-paid and funded by the National Health Fund. A wide-range discussion is difficult, as there are very few studies on the subject-matter in the available literature. Results different from ours, concerning the correlation between education level and the use of removable dentures, were obtained by Akar and Ergul [5] who did not find such 
a correlation for the elderly residents in nursing homes in Turkey. Evren et al. [6] discovered that edentulous patients with a low education and income levels did not wear any dental replacements significantly more often. Perea et al. [7] found that $80 \%$ of the respondents in Madrid who used removable replacements were less educated, and the result was statistically significant.

Our study showed that funded removable dentures are more frequently used in the age group 51-70 years. A Polish study conducted in 2003 pointed to the fact that $30 \%$ of people at the age of 67-74 had untreated missing teeth. It was also found that the average number of teeth in the oral cavity in different age groups was, respectively: 4564 years - 19.09 teeth; 65-74 - 12.50 teeth [8]. The data for 2009 provided by the programme "Oral Health Monitoring" show that the percentage edentulous Poles at the age 65-67 was as high as $43.9 \%$ of the population, and the masticatory function was preserved in only $49.6 \%$ of this group [9]. Undoubtedly, these results translate into high needs for prosthetic treatment.

Almost $70 \%$ of the studied population who wear removable prostheses had their dentures funded by the National Health Fund, i.e. free of charge, which is obviously convenient for patients in need of prosthetic treatment.

Our own study showed that removable dentures funded by the National Health Fund are used more frequently by the respondents living in cities, with a higher education level, and women (who wore such prostheses twice more often) than the respondents from villages, with a lower education level, and men. In the authors' opinion, a higher health awareness of better-educated respondents, an easier access to prosthetic care in cities, and, in the case of women, a greater concern for appearance may affect the determined facts.

In addition, European research found that there is a correlation between the income level, on the one hand, and teeth loss and removable dentures use, on the other. Li et al. [10] showed that in Denmark low income is correlated with edentulism in patients, while Pistorius et al. [11] discovered that among the users of removable dentures in Mainz, Germany, $65.4 \%$ had low education and $83.1 \%$ reported an income of less than 2000 EUR per person. The correlation between the income level and edentulism was examined by Listl [12] who analysed the SHARE Programme data from $14 \mathrm{Eu}-$ ropean countries (2006-2007). The programme was based on the surveys that involved respondents at the age $50+$. The level of income was compared with the use of dental prostheses, regardless of their number and type. Poland showed the lowest income among the studied countries. In all the countries, the use of dentures decreased with an increase in income. Only in Poland and Italy the situation was reverse. The Polish respondents in the income tercile 2 and 3 had the highest number of prostheses in comparison to the respondents in other countries: $61.07 \%$ and $58.72 \%$, respectively. To compare, the lowest results concerned Sweden: $9.36 \%$ and $5.10 \%$, respectively. In the income tercile 3 , the respondents from Austria used the highest number of dentures $-71.63 \%$, while those from Sweden wore the lowest number of dental prostheses $-25.72 \%$; in Poland the respective percentage was $49.87 \%$. Most probably, the latter result may be related to a greater number of lost teeth in peo- ple with higher income or to the fact that people with lower income, despite the loss of teeth, did not seek treatment with prosthetic replacement.

\section{CONCLUSIONS}

1. Almost $70 \%$ of the studied population that wore removable dentures had their prostheses funded by the National Health Fund.

2. In all age groups women used funded prostheses more than twice more frequently.

3. Dentures funded by the National Health Fund were used significantly more often by the respondents at the age 51-70, resident in a city, and with a higher level of education that the respondents in other age groups, places of residence, and with different education levels.

4. There is a correlation between sex, age, place of residence and education, on the one hand, and the use of removable dentures, both patient paid and funded by the National Health Fund.

\section{REFERENCES}

1. Schlegel-Zawadzka M, Wójcikowska A. Jakość życia człowieka dorosłego $\mathrm{z}$ uzupełnieniem protetycznym. Stomatol Współcz. 2013;20(1):26-34.

2. Ziętek M. Zdrowie jamy ustnej Polaków. Czas Stomatol. 2005;58:388-91.

3. Hilt A, Rybarczyk-Townsend E, Lubowiedzka-Gontarek B, WochnaSobańska M. Problemy zdrowotne jamy ustnej 35-44 letnich mieszkańców województwa łódzkiego. Przegl Epidemiol. 2012;66:133-8.

4. Douglas Ch, Shih A, Ostry L. Will there be a need for complete dentures in the United States in 2020? J Prosthet Dent. 2002;87:5-8.

5. Akar GC, Ergul S. The oral hygiene and denture status among residential home residents. Clin Oral Invest. 2008;12:61-5.

6. Evren BA, Uludamar A, Iseri U, Ozkan YK. The association between socioeconomic status, oral hygiene practice, denture stomatitis and oral status in elderly people living different residential homes. Arch Gerontol Geriatr. 2011;53:252-7.

7. Perea C, Suárez-Garcia MJ, Del Rio J, et al. Oral health-related quality of life in complete denture wearers depending on their socio-demographic background, prosthetic-related factors and clinical condition. Med Oral Patol Oral Cir Bucal. 2013;18:e371-80.

8. Wochna-Sobańska M, Borysewicz-Lewicka M. Stomatologiczne potrzeby lecznicze ludności polski w świetle epidemiologicznych badań wykonanych w 2003 roku w ramach programu ,Miesiąc totalnie zdrowego uśmiechu". Czas Stomatol. 2007;60:299-305.

9. Porębska H, Lella A. „Szczerbaty ekran”. Gazeta Lek. 2010;8-9:20-1.

10. Li KY, Wong MC, Lam KF, Schwarz E. Age, period, and cohort analysis of regular dental care behavior and edentulism: A marginal approach. BMC Oral Health. 2011;11:9.

11. Pistorius J, Horn JG, Pistorius A, Kraft J. Oral health-related quality of life in patients with removable dentures. Schweiz Monatsschr Zahnmed. 2013;123:964-71.

12. Listl S. Income-related inequalities in denture-wearing by Europeans aged 50 and above. Gerodontol. 2012;29:e948-55.

\section{Corresponding author}

Jolanta Szymańska

Chair and Department of Paedodontics, Medical University of Lublin,

7 Karmelicka Str., 20-081 Lublin, Poland

E-mail address: szymanska.lublin@gmail.com 